\title{
Project stockholder: an effective system for renewal and revitalization of dilapidated inner city areas
}

\author{
S. Javad Hossieni ${ }^{1} \&$ A. Nouroozi ${ }^{2}$ \\ ${ }^{1}$ Islamic Azad University, Iran \\ ${ }^{2}$ Omran \& Maskan Mantaghe Shargh Corp., Iran
}

\begin{abstract}
This article explains the major difficulties of metropolitan cities concerning their dilapidated inner city areas. In Iran, there are 57,000 hectares of such areas having three major characteristics. There are difficulties in accessing the city quarters due to narrow roads and alley ways, most of the buildings having unsafe structural condition, and the building sites being too small for any viable construction. 207 cities have been identified having such urban problems in Iran. Urban renewals and revitalization plans of these neighbourhoods, despite the support of government and changes in laws and regulations, have not been as successful as expected.
\end{abstract}

Keywords: project stockholder, urban regeneration, urban renewal, city planning, Iran.

\section{Introduction}

In Iranian society, about $70 \%$ of the general population live in urban areas. This ratio is currently growing very rapidly and the numbers of metropolitan cities are increasing respectively.

One of the most important problems of Iranian metropolitan areas, like the holy city of Mashhad, is the existence of the run down neighborhoods in the inner city areas.

Various methods have been devised to tackle this problem throughout the world and in Iran. Each method has its own strengths and weaknesses. The most important challenge is to find the capital resources needed for the purchase of the existing land and buildings, inadequate financial sources delays the projects far 
beyond their planned schedules; to overcome this challenge a new system has been devised. This new system called "Project Stockholder" and, has been successfully implemented on two major projects in Mashhad, Iran. This experiment has been successful in regard to satisfying the needs and wants of investors in one hand and increasing the pace of redevelopment in Mashhad in other hand. In this article, we try to describe the formation, theory, procedures, its social and economic effects, the main characteristics of its investors and the degree of its success in a concise manner.

\section{Overview}

The "Project Stockholder" system concentrates on the true participation of people in the project, by absorbing an array of small capitals where such capital often invested on unproductive ventures. $40 \%$ of current stockholders are females and other $60 \%$ are government employees. Through this system, stockholders become owners of the project. After completion of the project, the profits are calculated and distributed among the stockholders according to the amount of their shares. The development company takes $5 \%$ of resources and profits for the services provided for project.

The company issues stocks to acquire land, prepare design, and pay for $30 \%$ of actual construction expenses of the project. Bank loans, presale of units, and participation of other investors constitute the remaining sources of needed capital. The development company guarantees the principal plus a minimum profit to the investor.

\section{Background to the theory and the social issues of stockholder system}

Social studies about the owners and inhabitants of dilapidated and worn out areas of the inner city neighborhoods in cities like Mashhad show the following results: $[1,2,5,6,9]$

1. Over $70 \%$ of residents and the people who conduct a business in the area own the property.

2. More than $50 \%$ of homes have an area less than $200 \mathrm{sqm}^{2}$.

3. More than $90 \%$ of the families have very low income (below the poverty line) and are populated ( 5 to 8 persons)

4. Over $70 \%$ of the population are illiterate or have very little education.

These statistics reveal:

1. Worn out and dilapidated inner city areas are a serious problem for most of the Iranian metropolitan areas.

2. Revitalization, renewal or redevelopment of such areas is necessary.

3. Most of the people feel redevelopment is a positive move.

4. Yet, in practice they do not participate in the process as expected. 
5. Therefore it is important to devise new methods and systems to tackle the problems in such way that heightens the level of participation by the owners, inhabitants, and the authorities.

Project Stockholder is a system designed and implemented according to the above concerns and objectives. In this system the emphasis is on the benefits to the people through their participation on the project.

The collection of theories regarding people's participation in urban developments that has been discussed in the past two decades can be summarized in five theories by James Richly (government and participation), Sherry Stein (participation ladder), Scot Davidson (the wheel of participation) and David Deriksel (ways of participation). Combining these theories and considering the unique characteristics of such areas in Iran, we can categorize people participation in three groups:

1. Rhetorical participation

2. Limited participation

3. Real participation [6].

\section{Introducing "Project Stockholder"}

"Project Stockholder" is a method of raising the capital resources needed for the construction projects located in the dilapidated areas of inner cities, by gaining the participation of the existing owners in project, as well as, absorbing and organizing other small capitals.

Through this system the owners of stocks get a share in the project. At the completion of the projects, the profits are calculated and paid out to the stockholders according to the amount of their shares. Ability to return the stocks to the issuing company at the end or during the construction period is the factor for the popularity of this system. This can be done, because in most construction projects, units become sellable a short while after the construction phase has begun. It is important to note that the development company takes $5 \%$ for the management of the project.

The main objective of project stockholder is its reliance on the current property owners and their non cash capitals. The ceiling for the issuance of project stocks is set for the purchase of properties, preparation of design, and $30 \%$ of construction costs. Other sources of capital such as bank loans, presale of units or other joint ventures constitute the financial resources for the rest of the construction expenses. Project stockholder differs from construction bonds. They can be interpreted as documents representing a percentage of ownership.

\section{Social characteristic of the stockholders}

Characteristics of the Sara and Majd stock owners are highlighted in Table 1 below. In this table, gender, occupation, location, and number of stocks are shown. 
Table 1: Distribution of stockholders for Majd and Sara project according to gender, occupation, location and number of stocks.

\begin{tabular}{|c|c|c|c|c|c|}
\hline Description & Stockholders & Sara Project & Majd Project & Total & Percentage \\
\hline \multirow{4}{*}{ Gender } & Male & 1289 & 3182 & 4471 & $70 / 68$ \\
\hline & Female & 369 & 1639 & 2004 & $79 / 30$ \\
\hline & Company & 17 & 16 & 33 & $50 \%$ \\
\hline & total & 1671 & 4837 & 6508 & 100 \\
\hline \multirow{5}{*}{ Occupation } & Government Employees & 1084 & 2757 & 3841 & 59 \\
\hline & Self Employed & 567 & 1782 & 2349 & 36 \\
\hline & Wage earner & 17 & 16 & 33 & $50 \%$ \\
\hline & retired & 3 & 281 & 284 & $36 / 4$ \\
\hline & total & 1671 & 4836 & 6507 & 100 \\
\hline \multirow{3}{*}{$\begin{array}{l}\text { Place of } \\
\text { residence }\end{array}$} & Mashhad & 1337 & 3967 & 5304 & $5 / 81$ \\
\hline & Other towns & 334 & 870 & 1204 & $5 / 18$ \\
\hline & Total & 1671 & 4837 & 6508 & 100 \\
\hline \multirow{9}{*}{$\begin{array}{l}\text { Based on } \\
\text { number of } \\
\text { shares }\end{array}$} & Less than 1 share & 35 & 330 & 365 & $6 / 5$ \\
\hline & share1 & 1118 & 3210 & 4328 & $5 / 66$ \\
\hline & 2 to 5 shares & 389 & 1061 & 1450 & $28 / 22$ \\
\hline & 6 to 15 shares & 64 & 183 & 227 & $48 / 3$ \\
\hline & 15 to 25 shares & 38 & 27 & 65 & $99 \%$ \\
\hline & 26 to 100 shares & 20 & 22 & 42 & $64 \%$ \\
\hline & More than 101 & 7 & 4 & 11 & $16 \%$ \\
\hline & Total number of shares & 1671 & 4837 & 6508 & 100 \\
\hline & Value of shares & 14000000 & 180373500 & 194373500 & \\
\hline \multirow{3}{*}{$\begin{array}{l}\text { Owner } \\
\text { participation } \\
\text { according to the } \\
\text { number of } \\
\text { shares }\end{array}$} & Other owners & $000 / 50$ & $000 / 866 / 6$ & $000 / 916 / 6$ & 96 \\
\hline & $\begin{array}{c}\text { Omran and Behsazi } \\
\text { Shahri Co }\end{array}$ & $793 / 736 / 2$ & & $793 / 736 / 2$ & 4 \\
\hline & total & $793 / 786 / 2$ & $000 / 866 / 6$ & $693 / 189 / 7$ & 100 \\
\hline
\end{tabular}

The table shows that about $30 \%$ of the stockholders are female and since the rate of female activity in Iranian society is about $9 \%$ [6], the project stockholder system is a good way for them to take part in economic activities. Government employees, because of their jobs, often have very little opportunity to take part in economic ventures. To overcome this problem they need to cut from their duties and spend some of their time away from the office in peruse of their own personal financial interests. Project stockholder, is a good way to absorb their small capitals and invest it in urban development to make some profit on the side. It is interesting to know that $60 \%$ of the current project stocks owned by government employees.

We can also conclude from the table that people living in small towns that have limited access to monetary tools, are good candidates to become stockholder and invest their small capitals in development ventures. $18 \%$ of the current stockowners are people from such areas.

Table 1 shows $72 \%$ of the stockholders own one share or less. People who purchased more than 2 shares constitute $28 \%$ and owners of 16 or more shares amounts to only $1.5 \%$ of the stockholders. This shows that people with small capital are very numerous in the society and look for opportunities to invest in suitable ventures. Project stockholder is a very good vehicle for this purpose. 


\section{Organizational and economic benefits of the "Project Stockholder"}

1. Participation in profits of the large construction projects: due to high rate of appreciation in real estate values in Iran, there is high level of interest to invest in this field in Iranian society. Project stockholder is a good way for people with small capital to take part in such ventures.

2. Path to create better saving: since people can pay part of the price of the stocks in installments, the system encourages saving without too much pressure. The resulting high level of profits also encourages people to participate on the development projects.

3. Guarantees on the profit: since the company guarantees the principal and a minimum amount of profit, it is a very good investment instrument for the risk averter buyers such as females and people with little income in Iranian society.

4. Guarantees on repurchase of the stocks: the ability to sell the stocks to the issuing company insures the liquidity for the buyer. This is very important factor for the buyer during the financial emergencies that may rise in his personal life.

5. Purchase of stock by in instalments: buying stocks in installments makes it attractive for people with fixed income such as government employees. This group of people does not have large cash reserves, but can pay installments as they receive their monthly wages. By using this method, participation of various social groups on a long term bases is accomplished.

6. Lack of third person in the project: since project stockholder is private contract between two parties, the activity of the issuing company is not supervised by a third organization and the company has the more freedom to spend its resources on what it deems suitable. It is important to note that each project has a dedicated company formed for the sake of that particular project, and its accounts independent form the issuing company. Independent and registered auditors supervise the company's financial activities.

7. Secondary market control: stock issuing company by actively taking part in the market controls the radical shifts in stock prices and prevents relentless speculation of the stocks on the secondary market. Since the company has the information about the real value of the stocks, it can control the prices by publishing reports about the condition of the project and its stocks, issue additional stocks at its real value during erratic increases in stock prices, or buy back stocks during stock price decreases to stabilize the market.

8. The social effects of project stockholder: working in dilapidated inner city areas requires sensitivity toward its own social and physical issues. The action oriented urban management concepts concentrates on development and implementation, yet the events happened in the recent decades show that simple physical revitalization has evolved into more complex forms of "urban economics", "social revitalization", beyond "urban revitalization". In order word, the extent of the work goes beyond physical properties and enters into the field of "social and cultural revitalization".

Project Stockholder concept goes beyond its financial function as it deals with inner city development and affects the social functions as explained below. 


\section{Social development}

Social transformations in the recent decades show a strong relationship between the concept of social development with well designed social programs, quality of life and good governance. Variations and the number of social factors relates to the degree of social and economic development in a country. However the experts agree on several key factors in this regard. One of the key variables in social development is the notion of participation. Participation has been defined as" members of a group assist each other mentally, emotionally, physically and financially to achieve a common goal" [7].

Project stockholder is a manifestation of participation of property owners of the development area, people having small capitals, other investors, builders, and holders of other resources come together for the common goal of constructing a project. The positive effects of such activities can be seen in Sara and Majd projects. This concept can be worked out for other social and economic fields.

\subsection{Social capital}

Having adequate social capital is considered one of the pre-requisites for realizing good development. Although there is less agreement on ways to measure the human and economic capital, Ivan Light in 1970 used the term social capital to describe the form of economic development in the inner city areas.

According to this concept, the new capitalism brings about a constant demand for social capital. Satisfying this demand depends on many factors which are external to free market and economy. The issue of social capital is discussed on both individual and social levels. At the individual level, it can be thought on the cooperative level [3].

This is what project stockholder system can contribute to the society it serves since, the foundation to produce social assets, is co-operation. The other important factor that affects the relationship between the company and current inhabitants is the factor of trust. People by purchasing project stocks place their trust on the company, and this in turn, results in qualitative and quantitative expansion of stockholders and other interested parties in the process of revitalization and renewal of dilapidated inner city areas. This will enhance the social capital on the individual and social level.

\subsection{Enhancing sense of belonging to an urban environment}

People who live in these areas, have spent long years in their home or place of business often expanding 20 to 50 years [6].Therefore, they have developed long and deep relationships with each other, and their surroundings. These factors contribute to a deep sense of belonging to the neighborhood. This sense is constantly reaffirmed through the daily experiences of the inhabitants $[2,5,6,8]$.

People's participation in the stockholder program, can enhance this sense. In the actual experience of Majd project, in addition to the purchase of the stocks, 
some owners invested the value of their real estate property on the company, and by doing this they reaffirmed their sense of belonging to their old neighborhood.

\subsection{Expediting the process of revitalization and renewal of the dilapidated areas}

Although the project stockholder system is a way to fulfill the financial requirements of developing urban projects, yet people with other resources such as owners of real estates, tools and machinery, builders, managers, supervisors, providers of building materials, marketing firms and others can participate in the project. They can provide their assets and services and receive shares of the project accordingly. Since everyone feels like the owner of the project, they will be sensitive toward the quality of the work they perform and this in turn will results better performance and higher commitment to project schedule. Delays are one the biggest challenges of large public projects, making them totally unfeasible by the time they are completed in many instances.

Periodical meetings between the management and the stockholders make the information flow easier and the interested parties more responsive.

Stockholders naturally expect the highest return on their investments. Therefore, manager and decision makers performance are evaluated according to this criteria. These people will do their best to satisfy the stockholders expectation in order to stay in their position.

\subsection{Discouraging consumption and encouraging saving and investment}

In all judo Christian teachings including Islam, Christianity and Judaism, there is a special emphasis on work ethics, social activity, saving, and investing in productive ventures which results benefits to the society. In the fields of economics and sociology many experts set forth new theories, however, the most famous theory regarding the growth of capitalism belongs to Max Weber, the renowned British sociologist in his important book by the name of "protestant ethics and capitalism" [4].

In his view, work is form of God worship. And from whatever one makes; he should only keep the amount he needs. This notion produced a condition, where efficiency in work, investment, and simplicity in life created a hospitable atmosphere for growth. Project stockholder system, because of its unique nature, has the ability to absorb small capitals.

It creates a condition for people with little income to invest the in productive ventures in a city environment and enjoy its benefits. If such instrument is not available, these small capitals will be spent on the non-productive goods and cause more inflation.

\subsection{Creating legitimacy for the projects and reducing resistance}

Revitalization and renewal of urban areas can be considered successful when the social and economic resistance of people turns into participation and agreement. Yet, due the direct intervention by municipalities in the dilapidate areas for the 
sake of redevelopment, people have fiercely resisted these programs. This method has caused the failure of many projects by prolonging the land acquisition process and imposing heavy expenses where the project's feasibility becomes questionable. Project Stockholder seeks the participation of people living in the project area.

Moreover, due to the negative feelings created because of direct intervention and lack of benefits to current inhabitants, the resistance becomes more serious. Project stockholder gives the priority to these people with the aim is to resettle them in their original neighborhoods after completion of the project. Reaching this goal can create legitimacy for the project and reduce resistance to the program.

\subsection{Strengthening the social organizations and their role in urban management}

Studies concerning development of dilapidated areas show that municipalities and government cannot take the responsibility of redevelopment alone. The vast expanses of such areas coupled with lack of flexibility of public agencies often causes long project delays and create more undesirable areas [4].

Project Stockholder system is in agreement with the number 44 code of national constitution, regarding the privatization of public concerns and policies set forth on the fourth national development program regarding the reduction of the size of government.

At this end creating organizations acting as a liaison between people and government seems inevitable. These organizations, through proper public relations can create enough incentives for the current owners and inhabitants to participate in the project. They can also bring the programs concerning the support, governmental exemptions and incentives for the sake of redevelopment to the area. They can also assist cooperation of people with the project through constant and organized activities with the aim of distributing the benefits of the project on a just and equitable manner for all the participants. In this case the immense power of people is unleashed, and the magic of people's participation in urban development is formed.

Organization created according to the intent of the project stockholder system for sake of achieving the goals stated above, and implemented on Majd project, can be used on the other similar projects. This system is currently adopted on several other projects in Iran.

\section{Project conditions and the trend of stock value increase in Sara and Majd projects}

It is fortunate that stock owners of Majd and Sara project have enjoyed a very sizable increase in the value of their stocks. This increase in value is shown in Table 2. 
Table 2: $\quad$ The trend on value of stocks during 2007.

\begin{tabular}{|c|c|c|}
\hline 2007 months & Percentage increases in Sara & Percentage increases in Majd \\
\hline March & $981 / 16$ & $303 / 1$ \\
\hline April & $367 / 15$ & $264 / 1$ \\
\hline May & $042 / 17$ & $403 / 1$ \\
\hline June & $327 / 17$ & $495 / 1$ \\
\hline July & $729 / 19$ & $535 / 1$ \\
\hline August & $541 / 21$ & $697 / 1$ \\
\hline September & $972 / 22$ & $740 / 1$ \\
\hline October & $347 / 24$ & $818 / 1$ \\
\hline November & $292 / 27$ & $841 / 1$ \\
\hline December & $848 / 33$ & $884 / 1$ \\
\hline January & $427 / 31$ & $948 / 1$ \\
\hline February & $402 / 32$ & $937 / 1$ \\
\hline
\end{tabular}

In general, the value of stocks for Majd project shows $120 \%$ increase. It was offered at 100 Tomans a share (about 10 cents) and it has raised to 225 Tomans a share (about 25.5 cents). Sara project which started earlier show higher increase. It is currently shows about $300 \%$ increases in value. The original stock was offered at 1000 Tomans (about \$ 1) and it worth about 4000 Tomans (about \$4) presently.

For this reason, according to a study conducted in $2008,65 \%$ of stockholders have expressed their satisfaction with their stock performance. $80 \%$ were satisfied with the company's information systems regarding the stock values and its changes, 65\% were happy with the pace of the construction, and $72.5 \%$ expressed their satisfaction with the quality of transfer, sale and purchase of stocks.

\section{Conclusion}

The Dilapidate inner city areas is a serious problem for most the Iranian metropolitan areas. The present approach to reconstruct these urban sectors and lack of public participation not only slows the development process but also inflicts very high costs on the local authorities and central government.

On the other hand the "Project Stockholder" method is an alternative which causes the residents, public and the private sector to participate more and experience the social attachment.

Our case studies of the Majd and Sara projects in Mashhad, Iran demonstrates that the "Project Stockholder" method is the most efficient path that could capitalize on rounding up the smaller investors capitals and use it towards the 
reconstruction of these urban sectors with no burden on the central government and/or the city municipalities, thus the "Project Stockholder" is a WIN-WIN method which could achieve the common objective for all involved.

\section{References}

[1] Andalib, Ali reza. Renewal of dilapidate area, renewal organization of Tehran: Iran, 2006, pp: 30-45.

[2] Behravan, Hossien. Finding ways to encourage participation of people in urban renewal for tabarsi street, Shargh co: Mashhad, Iran, 2008, pp: 50-55.

[3] Fokoyama, Francis. The end of order, the social capital and ways to preserve it, 2006, pp: 110-115

[4] Frond, Julian. Sociology of Marx, Abdolhossein nikgohar, Tehran, Nikan Publishing, 1981, pp: 120-122

[5] Hammed Moghadam, ahamd. Opinion study of people living in vicinity of emam reza shrine in Mashhad, 2007, pp: 110-115.

[6] Hossieni, Seyed Javad. People's participation in urban renewal and revitalization of dilapidate areas, Majd project, Shargh co: Mashhad, Iran, 2008, pp: 160-162.

[7] Jamali, Mohammad jafar. Ways to improve quality of housing in dilapidate areas of the city, Organization of Iranian municipalities: Tehran, 2007, pp: $50-52$.

[8] Kahrobaiee, Ali reza. Social study of areas near the shrine of emem reza, Iran, 2006, pp: 170-172.

[9] Taash. Consulting engineers, Mashhad master plan, ministry of Housing and Urban Development, Iran, 2005, pp: 90-93. 